るようになってきた。このようなメッキのプロセスの 確認は,メッキされたノッチ付きテスト・ピースやリ ソグを使ったサステインド・ロード・テスト (sustained load test)により行なう.

メッキ後の塗装す保護皮膜として重要視されてきて おり, 二トロセルローズ系塗装加らエポキシ塗装, ポ リウレタン埲装と変わりつつあり,それにつれて塗装
のプロセス・コントロールが峳しく要求される,ように なってきている。

\section{参考資料}

1) David Bruce TrEmblay: Landing Gear System Analysis. ASD-TR-69-113.

2) H.G. Conway: Landing Gear Design,

\title{
航空機の空気調和装置のすう勢* \\ Trend in Aircraft Air Conditioning
}

\section{1.まえがき}

航空機に使用されている空気調和装置とは，空気を 適当な温度および適当な湿度に調整して，操絉室およ び客室に送り込む装置をいう。

空気調和装置を考える上で，すなわち長所・短所あ るいは最適設計について論ずる場合に，どうしても考 えなりればならない条件として次のようなあのがあ る.

与圧室を有する航空機においては，空気調和方式を 比較する場合，与压との関連性を考慮に入れる必要が ある. 飛行中，乗員と乗客に新鮮な空気を供給すると 同時に与王室を与代するためには，空気調和方式のい かんにかかわらず，ある最低限の圧力空気を与压室に 供給する必要がある。

性能について検討する場合には，空気調和装置の入 力と出力を正しく評価する必要がある.入力として, 航 空機のエンジンよりブリード空気 (engine bleed air) を抽出したことによる航空機の推力の低下，熱交換器 冷却空気を得るために生じる航空機の抵抗損失，その 他空気調和装置に消費さ机る電力等の動力消費が考元 られ，出力としては，冷房能力，暖房能力，温度制御 性能などが考えられる。

航空機の空気調和装置に現在まで用いられて来た方 式を大別すると，熱交換器と冷却タービンによってキ ヤビン供給空気を直接に命却するエヤ・サイクル（air cycle) とフレオンなどの冷媒によってキャビン供給空 気を冷却するべーパ・サイクル（vapour cycle）とが ある。

エヤ・サイクルの長所は，冷房に必要な空気源は， 与圧のための空気源でもあるほどてとである.という

*昭和 48 年 9 月 28 日原稿受理

**株式会社 島津製作所
田 中 宣 次**
Nobuji TANAKA

のは，飛行高度が高くなればなるほど高差圧の与圧が 要求されるか゚，冷房負荷は小さくなり逆侸暖房が必要 な場合が生じる，また，高度が低くなればなるほど低 差圧の与圧でよいが冷房負荷が大きくなる．とのよう にエンジン・ブリード空気の圧力エネルギーが有効に 利用されることは，航空機の空気調和装置にエヤ・サ イクルが適している有力な理由である。て机に対して ベーパ・サイクルでシステムを構成する場合には，べ 一パ・サイクルを運転するのに必要な動力源とは別に 与压に利用できるキャビン供給空気をエンジン・ブリ 一ド空気として得るがるいは別にコンプレッサーを 装備して圧力空気を得るかしなり机ばならない．

ベーパ・サイクルの最大の利点は, 冷媒用コンプレ ッサーやコンデンサー・ファンを電動式とした場合, 地 上静止時们電源のみで冷房作用が行なえる点である.

保守, 点検, 補充等整備上の面では, ベーパ・サイ クルは，冷媒を完全億封する必要があるため，エ ヤ・サイクルに比較して, 本質的に信頼性が低い.

\section{2. エヤ・サイクル空気調和装置の作動}

現在航空機に使用されている空気調和装置のほとん ぞがエヤ・サイクルであるので，以下に中型輪送機に 使用されている代表的な装置についてその作動を説明 する. 第 1 図にエヤ・サイクル空気調和装置の一例を 示す.

空気調和装置の空気源として，エンシンから抽出さ れたブリード空気が使用されている. 本例のブリード 空気の圧力は, ある飛行条件で約 $7 \mathrm{~kg} / \mathrm{cm}^{2} \cdot \mathrm{abs}$, 温度 は約 $260^{\circ} \mathrm{C}$ である、このブリード空気は, 圧力調整去 の入ロより流入し，一定流量に制御されて一次熱交換 器に流入する. とてでラム・エヤ・スクープによって 大気より取り入れられた冷却空気によって冷却されク ーリング・タービン (cooling turbine) のコンプレッ 


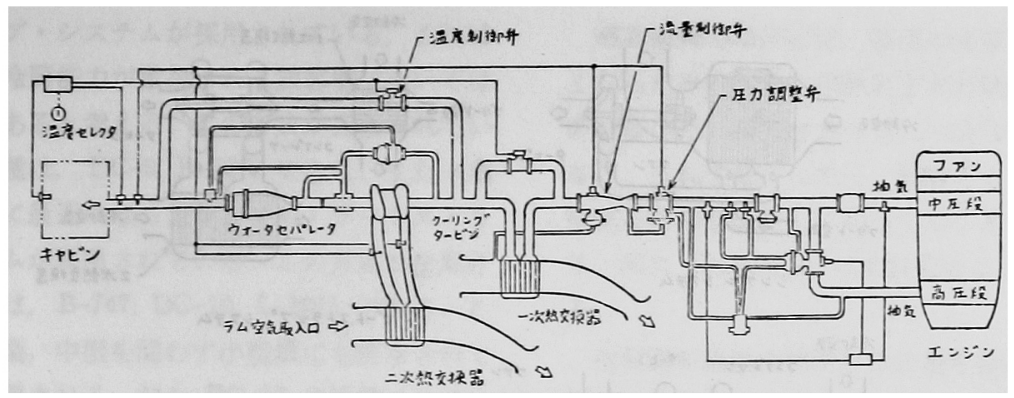

第 1 図 空気調和装置系統図

サ一側に流入し，断熱圧縮されて圧力上昇・温度上昇 をとすなって二次熱交換器に流入する，乙の空気は， 二次熱交換器により再び椧却されて，クーリング・タ 一ビンのタービン側に流入し，断熱膨張によって約 0 ${ }^{\circ} \mathrm{C}$ の以下の温度言で冷却される。この空気は，通常 過飽和であるのでウォータ・セパレータ（water separator）によって余分の水分が除かれる. 一方，クーリ ング・タービン入口からバイパスされたホット・エヤ (hot air) は，クーリング・タービンの下流でクーリ ング・タービンから流出したコールド・エヤ(cold air）之湿合される. 温度制御回路は，客室およひ操赫 室の温度が温度設定セレクタで指定された温度になる ように温度制御弁を作動させ，ホット・エヤとコール ド・エヤの混合比を定める。

上記の過程を释て所望の温度に制御された調和空気 が客室わよび操咬室飞供給される。

第 2 図は，中型输送機化使用されているクーリング ・タービンを，第 3 図は，熱交换器を示す．また第 4 図および第 5 図は，クーリング・タービン，熱交換 器, 流量制御弁その他制御用バルブを一体にまとめ, リフリジェレーション・ユニット(refrigeration unit) として構成したすのである.

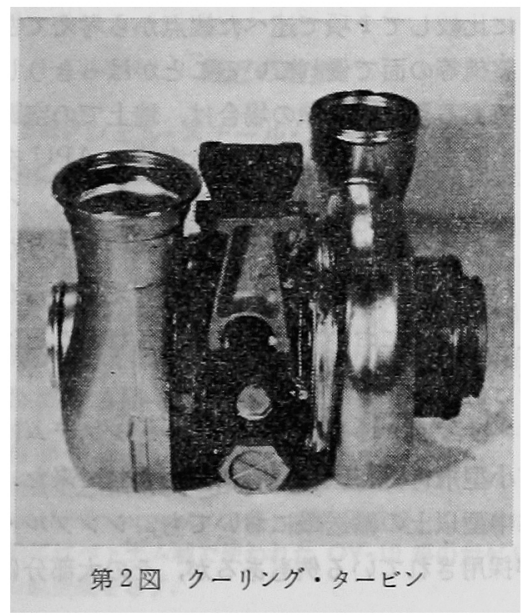

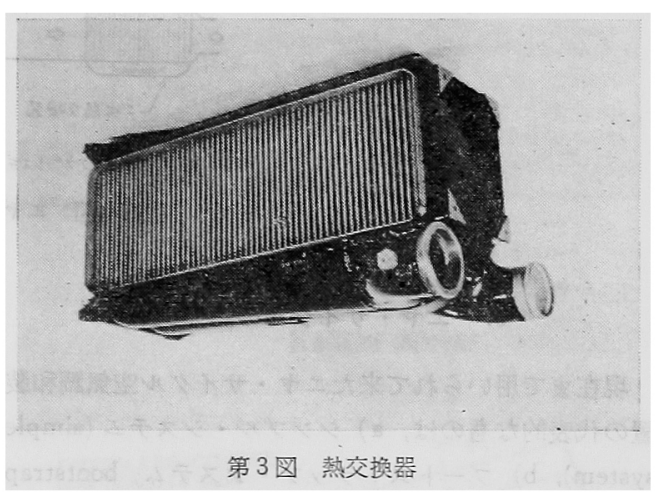

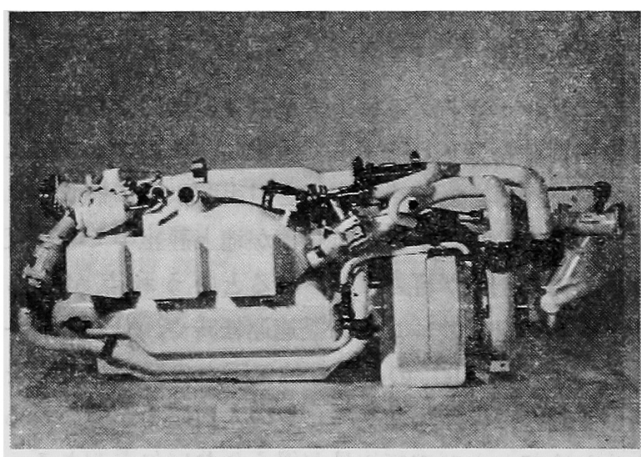

第 4 図 レフリジレーション・ユニット

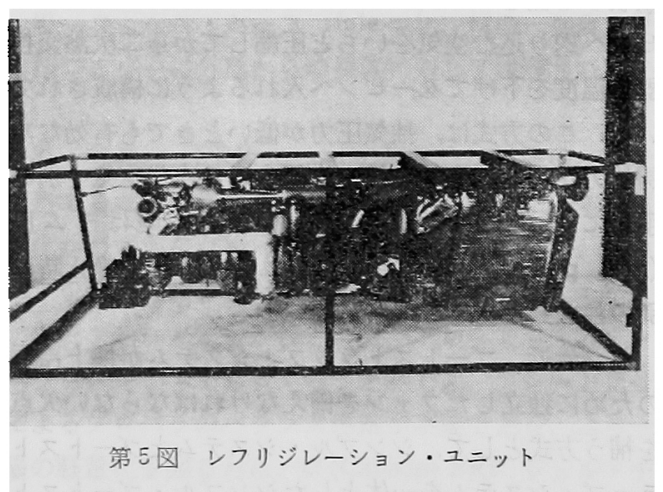




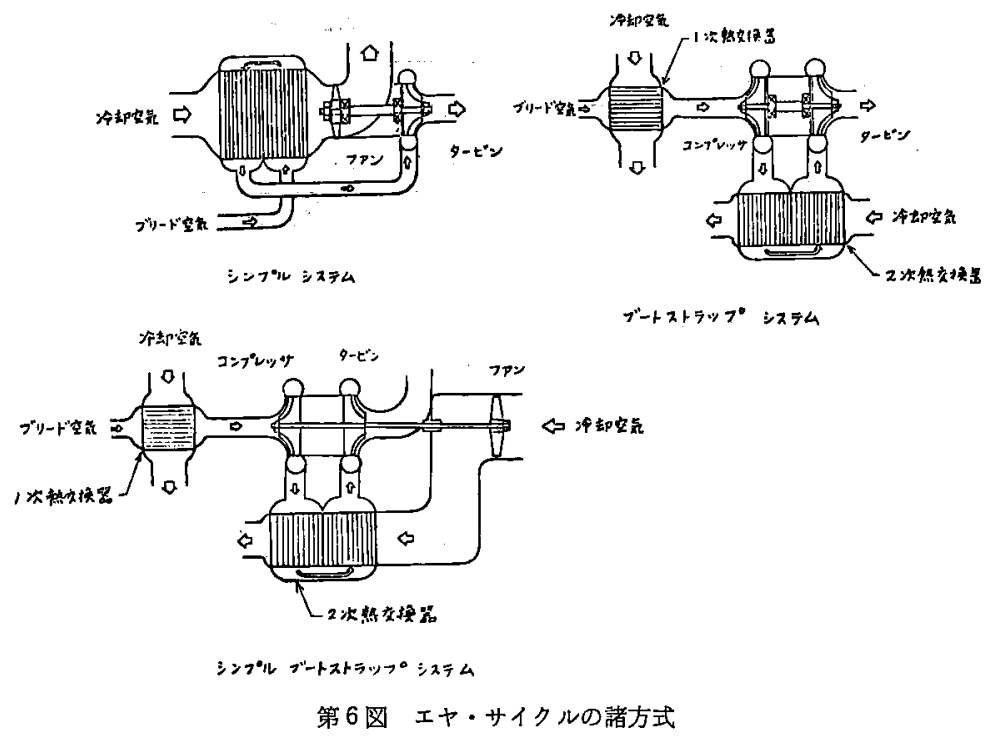

\section{3. エヤ・サイクルの諸方式}

現在まで用いられて来たエヤ・サイクル空気調和装 置の代表的なすのは，a) シンプル・システム (simple system), b) ブートストラップ・システム bootstrap system) および, c) シンプル・ブートストラップ・シ ステム (simple bootstrap system) である.これらを 第 6 図に示す.

シンプル・システムは，タービンの動力をとれと同 軸に取付けたファンによって吸収し，とのファンによ って熱交換器を通る冷却空気を引出すように構成され ている．乙の方式には，航空機が地上静止中であ熱交 換器の冷却空気が自力で得られるという利点がある が, 反面地上でのエンジン緩速運転時や, APU (auxiliary power unit) の上うな抽気王力の低い空気源を 用いる場合には，冷却タービンの入口圧力が低いため 十分な冷却および空気流量が得られない欠点がある.

ブートストラップ・システムは, タービンの動力を 吸収する側をコンプレッサーよし，これによってキャ ビンへ送り込む空気をいちど樎してから二次熱交換 器で温度を下げてタービンへ入れるように構成されて いる.との方式は，抽気圧力が低いときでも有效な冷 房能力が得られるが, 熱交換器を通る冷却空気を別の 手段によって得なければならない，飛行中はラム圧 (ram pressure) によって得られるが，地上静止時は 別の独立したファン等が必要である.

なお最近，ブートストラップ・システムが地上冷房 のために独立したフォンを備えなりればならない欠点 を補う方式として，シンプル・システムとプートスト ラップ・システムを一体としたシンプル・プートスト
ラップ・システムと呼ばれる方法が使用されるように なった.との方式は，タービン，コンプレッサおよび ファンを同一軸上に組込んで構成したもので, 地上静 止時す熱交換器の冷却空気をこのファンで得ることが 出来る、このクーリング・タービンは,タービン, コ ンプレッサおよびファンの適切な動力バランスが必要 であり，構造も複雑となるので；シンプル・システム およびブートストラップ・システムに比較して高度な 技術を必要とするが, 非常に有力な方法と考えられる。

\section{4. 現状と将来}

現在航空機に使用されている空気調和系統では，工 ヤ・サイクルがその主流を占めている。それは, 現在 運行されている航空機を調査するとただちに明白とな る，たとえば中型以上の輸送機でベーパ・サイクルを 採用しているのは DC-8, Convair 880, VC-10 等数 機種にすぎない，とれはエヤ・サイクルがベーパ・サ イクルに比較して 1 項で述へた観点から考えて性能,

重量, 整備等の面で優れていることがはっきりして来 たからであろう．旅客機の場合は，地上での空調がど うしても必要であるが，最近は航空機に APUを塔载 することが普通となっている。このことから，ベーパ ・サイクルはヘリコプターやビジネス機のような小型 機においては採用されるととが十分考えられるが，中 型以上の輸送機においては今後採用されるととはほと んごなくなるあのと考えられる。

エヤ・サイクルのうちでシンプル・システムは, 主 として小型飛行機，戦闘機等に使用されて来た.ごく まれに中型以上の輸送機においても，シンプル・シス テムが採用されている例もあるが，その大部分は，ブ 
ートストラップ・システムが採用されている。てれは 地上における冷房能力が重視される旅客機においては 当然の結果であると考える. ての方式が採用されてい る代表的な機種は，DC-9； B-727，である．また 3 項 で述べたように最近になってシンプル・ブートストラ ップ・システムが採用されている：乙の方式が使用さ れている機種は，B-747，DC-10，L-1011 がある。乙 の方式は，大型，中型を問わず小型機にも使用されて 行くことが予想される。なお DC-10 に塔載されてい る米国 Airesearch 社のクーリング・ユニットは，軸 受に空気軸受を使用し，問題になりがちな軸受および 潤滑の問題を解决している.
超音速機の場合には，高速によりラム空気温度が高 くなるため, 従来の空気対空気の熱交換器だけではそ の冷却作用に限界があって，十分な冷房能力が得られ ない，てれを補うために，燃料あるいはキャビン排出 空気を冷却空気として利用するてとを考える必要があ る.現に Concorde はてれらのととが考慮されてい る.

空気調和装置の技術進歩の跡を振返ってみると，短 期間任常な進歩をとげたという印象はない，しかし 各構成部品において着実な進歩の跡がみられる. 今後 あ同様の進展が考えられる.

\section{航空機用プロペラのすう勢* \\ Trend in Aircraft Propeller}

\section{木 敬 一**
Keiichi KIBIKI}

\section{最近の情勢}

最近のファン・エンジンの進歩によって, 中長距離 翰送譏の推進機関の主流はファン・エンジンになり, プロペラの用途は主として短距離輸送機, 軽飛行機, 特殊用途機〔CO-IN***, コンパウンド・ヘリコプタ - (compound helicopter) 等了に限られるようにな った. 旅客機などでは, “より早く”“プロペラ機は時 代荤㣗”といった乗客の要求, 心理に乎応して, 本来 プロペラ機の方が経済的に適しているような短距離区 間にもジェット機が使用されるようになってきた。

かかる情勢の中にあって,ターボファンとの対抗 上,また, 軽量化, 整備性の向上といった時代の要請 に答えるため種々の試みがなされ，多くの進歩が生ま れた. そのいくつかを以下に紹介する.

\section{最近の進歩}

1. FRPシェル・スチール・スパー・ブレード(FRP Shell-Steel Spar Blade) 1960 年代初め, V/STOL を主な対象として，大型軽量のプロペラの研究開発が 始まり,その結果として第 1 困に示すような G (Glass) FRP シェル・スチール・スパー・ブレードが開発さ れ，1960年代後半には実用化された。実機採用例とし ては P-2H, AH-56A， XC-142A などがある.

\footnotetext{
*昭和 48 年 12 月 21 日原稿受理

**住友精密工業株式会社

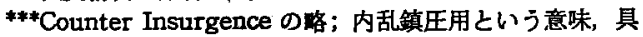
体的にはベトナム戦で使われた OV-10 等の対ゲリラ戦 用の航空機をさす.
}

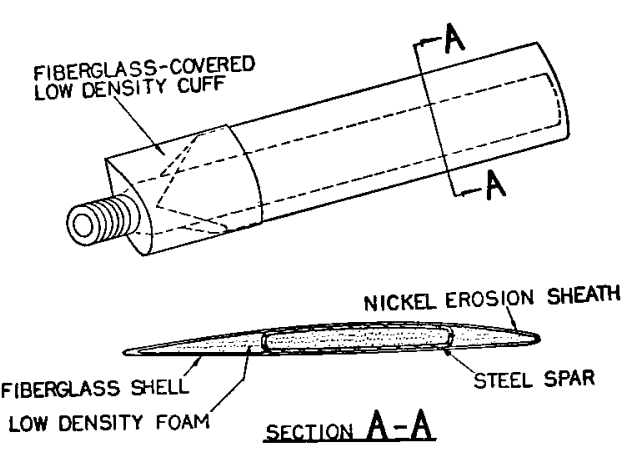

第1図 FRP シェル・スチール・スーパー・ブレード

このブレードの特徽とするところは，

1) 軽量一従来のソリッド・アルミ・ブレード(solid aluminum blade) に比べて 15 50\% 㪕くできると言 わ机てる.

2) フェール・セーフ (fale-safe) 構造一強度を受 け持つスパーは外部からの損傷に対して保讙されてい る.

3）整備性一FRP シェルの局部的な損傷はパッチ を当てるだけで修理ができる．また，修理による重量 変化がわずかなため, 再バランスの必要がなく、プロ ペラを機体に装着したままで修理ができる.

またブレード重量が軴いため，ブレード単体のアン バランスを小さくおさえるととができ，ブレード交換 によるプロペラのバランス作業が不要である。よりー 層の軽量化を図るため，C (Carbon) FRP シェル・チ タニゥム・スパー・ブレードが現在試作の段階にあ 